\title{
Reseña de Gonzalo García, Rosario Consuelo, El legado bibliográfico de Juan Pérez de Guzmán y Boza, duque de T'Serclaes de Tilly: aportaciones a un catálogo descriptivo de relaciones de sucesos (1501-1625), Madrid, Arco Libros, 2018, 1154 pp. ISBN: 978-84-7635-969-3
}

\section{Gabriel Andrés}

http:/orcid.org/0000-0003-3229-4229

Università di Cagliari

ITALIA

andres@unica.it

[Hipogrifo, (issn: 2328-1308), 7.2, 2019, pp. 911-913]

Recibido: 02-08-2019 / Aceptado: 21-09-2019

DOI: http://dx.doi.org/10.13035/H.2019.07.02.63

El estudio de R. Consuelo Gonzalo García sobre el legado bibliográfico del Duque de T'Serclaes y su fondo de relaciones de sucesos impresas entre 1501 y 1625 dentro y fuera de la Península (285 son hoy día las conocidas y analizadas en este estudio) ha visto la luz en una voluminosa edición de la madrileña editorial Arco Libros. La obra había sido galardonada años atrás con el Premio de Bibliografía de la Biblioteca Nacional de España (2014) y dificultades institucionales - signo de los tiempos actuales para el sufrido mundo de la cultura- postergaron más de lo debido su necesaria publicación. Felizmente, desde 2018 este trabajo ha quedado incorporado en la prestigiosa colección Tipobibliografía Española de dicha editorial que, con esta nueva entrega, nos sigue ofreciendo -junto a obras imprescindibles de Julián Martín Abad y Mercedes Fernández Valladares, entre los estudiosos de reconocido prestigio - otro primordial instrumento bibliográfico para historiadores de la literatura, de la cultura y específicamente del libro desde los orígenes de la imprenta en ámbito ibérico.

En este trabajo se nota, en primer lugar, la filiación investigadora de la autora dentro de un terreno de estudio que bien conoce, el de las relaciones de sucesos como género editorial, textual y proto-periodístico, que ha merecido una destacada atención desde hace ya décadas por parte del grupo de investigación S.I.E.R.S. 
(Sociedad Internacional para el Estudio de las Relaciones de Sucesos: <www.siers. es>), cuya labor la autora también ha sostenido ocupando cargos de gestión en su junta directiva. En este ámbito, R. Consuelo Gonzalo ha contribuido con numerosos artículos y ponencias, particularmente interesantes en el caso de impresos postincunables y pliegos góticos de difícil localización, junto a raros pliegos sueltos posteriores, ahora en buena parte reunidos en este volumen de aportaciones, como señala el título, a un catálogo descriptivo de relaciones de sucesos. También ha contribuido a esa misma tarea publicando con anterioridad una guía para la documentación e investigación sobre estos materiales (Biresu): La Biblioteca del relacionero: repertorios, catálogos y otras fuentes de información para la localización de las Relaciones de Sucesos (A Coruña, Sociedad de Cultura Valle Inclán-Universidade da Coruña, SIELAE, 2010). Un trabajo este que aúna uno de los ámbitos de investigación preferentes de la investigadora con su perfil académico como profesora de la Universidad de Valladolid en el sector de la Documentación y la Traducción.

Precisamente este quehacer en la enseñanza universitaria queda patente en el volumen aquí reseñado, pues ya desde sus primeras páginas se despliega en él un inusitado esfuerzo de precisión, orden y claridad que hacen del extenso «Estudio introductorio» (pp. 17-326) un auténtico manual sobre el mundo de la bibliofilia española en la segunda mitad del siglo XIX -capítulo 1 («Las relaciones de sucesos como objeto de interés bibliofílico e historiográfico en la segunda mitad del siglo XIX») y capítulo 2 ( «Juan Pérez de Guzmán y Boza, duque de T'Serclaes de Tilly, y su biblioteca»)-, así como sobre los fundamentos de la bibliografía material (capítulo 3) con los planteamientos necesarios para hacer frente a la no siempre fácil tarea de descripción y estudio atento de este tipo de piezas.

Por lo que se refiere al rico legado bibliográfico del Duque de T'Serclaes de Tilly, don Juan Pérez de Guzmán y Boza (1852-1934), este constituyó en su tiempo una de las mejores bibliotecas privadas de España en lo referido a relaciones de sucesos, siguiendo en este terreno su propietario, como bibliófilo y erudito, la senda abierta por la obra de Jenaro Alenda, Relaciones de solemnidades y fiestas públicas de España (1903); una biblioteca, la del Duque, completada en otro tipo de impresos por la reunida por su hermano y también bibliófilo Manuel, marqués de Jerez de los Caballeros, en buena parte depositada hoy día en la Hispanic Society of America gracias a la adquisición que realizó a principios del siglo XX Archer Milton Huntington. De modo que en su día, como se lamentaba Pascual de Gayangos, los dos hermanos acaparaban una parte importante de las subastas y del comercio de impresos antiguos españoles.

En el caso del Duque de T'Serclaes, senador por Badajoz y diputado por Sevilla y Écija a finales del siglo XIX, miembro de la Real Academia de la Historia desde 1908, aunque no se hizo en vida una catalogación de su biblioteca, primero situada en Sevilla y luego trasladada a Madrid, esta sirvió de referencia para numerosos estudiosos en su día -incluido Marcelino Menéndez Pelayo- gracias a la disponibilidad del propietario para facilitar sus fondos a los eruditos y conocidos que frecuentaban asiduamente su casa como amigos y contertulios, o bien como ocasionales visitantes. Tras su muerte, los fondos de la colección quedaron intervenidos duran- 
te la Guerra Civil por la Junta de Protección del Tesoro Artístico Nacional, depositados primero en la Biblioteca Nacional, luego en Valencia, para acabar en Ginebra en manos de la Sociedad de Naciones. Reclamados por los herederos al fin de la contienda, regresaron para ser repartidos en varios lotes entre aquellos, hasta que, tras su dispersión posterior con los años, la reciente colaboración con la autora por parte de algunos de los nietos del Duque ha permitido dar cuenta de una parte importante de los ejemplares originarios del fondo, así como reconstruir -también a partir de la correspondencia del propietario con sus amigos e intelectuales Manuel Gómez Imaz, Luis Montoto, Aureliano Fernández Guerra, Francisco Asenjo Barbieri, etc. (véase apéndice 9.2) - el universo biográfico de los intereses bibliofílicos del Duque, así como la suerte de algunas series de impresos de particular relevancia, como los 55 adquiridos a través del librero Jacques Rosenthal, en algunos casos ejemplares únicos (capítulo 2.4).

En particular, en el tercer extenso capítulo de su estudio introductorio («Objetivos y metodología para el análisis y la descripción de relaciones de sucesos») se aprecia el rigor metodológico adoptado en las descripciones analíticas minuciosas de las ediciones, completando cada noticia tipo-bibliográfica con la información sobre la historia de su transmisión y difusión textual. El resultado es un repertorio en el que se reconstruye la historia textual, tipográfica y editorial de las relaciones de sucesos hoy día localizadas de aquel rico fondo del Duque de T'Serclaes, con una escrupulosidad y riqueza de datos complementarios (diversas ediciones y estados de edición, versiones y copias manuscritas, traducciones, propietarios diversos en el tiempo, noticias en catálogos y repertorios, etc.) difícil de superar, haciendo de toda esta sección una guía de referencia y modelo a seguir en el futuro. Basta por otra parte observar la sección 8.1. («Cuadro sinóptico de la estructura de las noticias bibliográficas») y seguir en filigrana su estructura proyectada en cada una de las entradas a lo largo del repertorio para apreciar el tesón metodológico y la capacidad de recuperar e integrar datos histórico-bibliográficos útiles a partir de todo tipo de fuentes.

El volumen con la descripción y análisis de parte del fondo T'Serclaes logra ser representativo de las noticias que circularon dentro y fuera de España entre 15001625, facilitando además su estudio, junto a varios apéndices complementarios, a partir de diez instrumentos de consulta (capítulo 6), que incluyen índices de autores y traductores, onomástico complementario, toponímico, tipográfico-cronológico, de materias, de primeros versos, relación de bibliotecas con ejemplares localizados, índice de ex-libris, superlibros y procedencias... Toda una lección magistral en el terreno de la documentación sobre impresos de relaciones de sucesos. 